\title{
Optimum and comparison of theoretical \& experimental results of an industrial secondary reformer reactor in basra fertilizers plant at different operation plant efficiencies
}

\author{
Ali Ashour AL-Dhfeery ${ }^{*}$, Ala'a Abdulrazaq Jassem \\ Department of Chemical Engineering, Basra University, Basra 42001, Iraq \\ Email address: \\ chemicalengineer82@yahoo.com(A. A. AL-Dhfeery)
}

To cite this article:

Ali Ashour AL-Dhfeery, Ala'a Abdulrazaq Jassem. Optimum and Comparison of Theoretical \& Experimental Results of an Industrial Secondary Reformer Reactor in Basra Fertilizers Plant at Different Operation Plant Efficiencies. American Journal of Chemical Engineering. Vol. 1, No. 1, 2013, pp. 17-23. doi: 10.11648/j.ajche.20130101.14

\begin{abstract}
This study aims to evaluation the optimum performance of industrial Secondary Reformer reactor in the State Company of Fertilizers South Region in the Basra/Iraq relative to Different Operation Plant Efficiencies of ammonia plant at $100 \%, 70 \%$ and $65 \%$ through study the effect of different molar flowrates of air. The effect of air molar flowrates on the cooling water around the Secondary Reformer reactor have been described in this study. The analysis feed Process Gases compositions to the industrial Secondary Reformer reactor in the laboratory is used as data in the mathematical model then comprised these results with the values of industrial Reformat Gases which are tested in laboratory too. The optimum molar flow rate of air is specified at different efficiencies of Ammonia plant $100 \%, 70 \%$ and $65 \%$.

The Secondary Reformer consists of two sections, the combustion and catalyst which is filled with nickel-containing reforming catalyst. It is placed after the primary reformer in ammonia plant at fertilizer plant. The Secondary Reformer reactor is used to produce Reformat Gases which are consisted from synthesis gas (Hydrogen and Carbon Monoxide) to Nitrogen mole ratio of 3 to 1 . Finally, the optimum results of air molar flowrates at operation efficiency $100 \%, 70 \%$ and $65 \%$ found $1750.50,1224$ and $1136 \mathrm{Kmol} / \mathrm{hr}$ respectively.
\end{abstract}

Keywords: Mathematical Model and Simulation, Autothermal Reforming Reactions, Catalyst, Hydrogen Production

\section{Introduction}

Reformer reactor is the principal equipment today to produce Hydrogen and synthesis gas from fossil gaseous and liquid hydrocarbons such as primary, secondary and autothermal reformers. Synthesis gas is a major route from hydrocarbons to many important chemicals made up from $\mathrm{H}_{2}$ and $\mathrm{CO}$. The traditional technology of Synthesis gas production is steam reforming reactions of Hydrocarbon. Steam reforming of methane shows highest Hydrogen production efficiencies. Hydrogen is used in nearly $80 \%$ of all ammonia plants and will probably become even more important in the future.

In the conventional reforming process in the Ammonia plants, the primary reformer reactor is utilized to produce Process Gases which consist of Methane, Hydrogen, Carbon Monoxide, Carbon Dioxide, Water vapor and Nitrogen.
The air is compressed to the reforming pressure and heated further in the primary reformer convection section to around $550^{\circ} \mathrm{C}$. The Process Gases from the primary reformer reactor is mixed with compressed air, usually the Process Gases and air are reacted further to $1000^{\circ} \mathrm{C}$ in the combustion section before entering the catalyst section[1]. There is a tendency to use Nickel containing catalyst $\left(\mathrm{Ni} / \mathrm{MgOAl}_{2} \mathrm{O}_{3}\right)$ to increase conversion in the catalyst section[2]. The heat of the reforming reactions is supplied by burning Process Gases with Oxygen of air in the combustion section.

In the recent and past decades, some authors evaluated optimum performance of catalyst and operation conditions of secondary or Autothermal reformer reactor such as, Ali AL-Dhfeery and Ala'a Jassem[2], Shukri et.al[3], Hoang and $\mathrm{Chan}[4]$, Y.H.Yu[5].

The importance of this work is presented in this paper to study the optimum air molar flowrate at each operation 
efficiency $100 \%, 70 \%$ and $65 \%$ for ammonia plant in the State Company of Fertilizers South Region. Also, it studied effect of air molar flowrate on the cooling water around the Secondary Reformer reactor, the originality of the work lies in this proposal.

The industrial data which is collected from the manual and daily log sheet of inlet Process Gases and air will be investigated, specified, monitored and tabulated relative to the actual operation conditions of industrial Secondary Reformer reactor in Basra Fertilizers Plant. Then, Some of these results of experimental work will be used in the mathematical model. The theoretical results are predicated from mathematical model will be compared with the industrial data of Reformat Gases which is tested in the laboratory of Basra Fertilizers Plant.

These data have been used for evaluating optimum performance of industrial Secondary Reformer reactor through, studying the effect of air molar flowrates at Different Operation Plant Efficiencies of Ammonia plant $100 \%, 70 \%$ and $65 \%$.

\section{Experimental Work}

The chemical compositions analysis of the Process Gases (Feed) and Reformat Gases (Products) is carried out at Different Operation Plant Efficiencies in the laboratory of the State Company of Fertilizers South Region in the Basra/Iraq.

The laboratory system consists of many instruments and tools such as sample cylinder, Gas chromatography (G.C.), Immersing Condenser is immersed in an ice bath and Gas flowmeter.

The analysis of inlet and outlet gases of industrial Secondary Reformer reactor in Basra Fertilizers Plant has been carried out relative to the industrial conditions where various samples of gases such as $\left(\mathrm{CH}_{4}, \mathrm{H}_{2} \mathrm{O}, \mathrm{H}_{2}, \mathrm{~N}_{2}, \mathrm{CO}\right.$ and $\mathrm{CO}_{2}$ ) is taken from the inlet of an industrial Secondary Reformer reactor by using a sample cylinder then, they are analyzed by the Gas chromatography (G.C.) to evaluate the mole fraction of gases. The results of the analysis have been performed at different plant efficiencies 100\%, 70\% and $65 \%$.

The ratio of steam to gases $(\mathrm{S} / \mathrm{G})$ has been carried by separation process to removing steam from other gases such as $\left(\mathrm{CH}_{4}, \mathrm{H}_{2}, \mathrm{~N}_{2}, \mathrm{CO}\right.$ and $\left.\mathrm{CO}_{2}\right)$. Steam and gases are separated by condensing Process Gases with ice. Remaining gases $\left(\mathrm{CH}_{4}, \mathrm{H}_{2}, \mathrm{~N}_{2}, \mathrm{CO}\right.$ and $\left.\mathrm{CO}_{2}\right)$ have been measured by using gas flow meter to evaluate volume of gases.

Process Gases compositions are determined by using a Shimadzu Model GC-9A gas chromatograph (G.C) which is consisted from dual columns, and a thermal conductivity detector (TCD). Ultra-high purity (UHP) Helium is used as carrier gas. It is used to Separation of the five gas products $\left(\mathrm{H}_{2}, \mathrm{CH}_{4}, \mathrm{~N}_{2}, \mathrm{CO}, \mathrm{CO}_{2}\right)$. Shimadzu Class-VP software is used for data acquisition. The G.C is operated at conditions as shown in Table (1).
Table (1) Operation conditions of gas chromatography [6]

\begin{tabular}{ll}
\hline Carrier Gas & Helium \\
\hline Column Temperature & $65^{\circ} \mathrm{C}$ \\
TCD Temperature & $100^{\circ} \mathrm{C}$ \\
Electric Current & $45 \mathrm{~mA}$ \\
\hline
\end{tabular}

Type of each gas has been limited by calibration of the G.C by using standard bottles of each gas (Air, $\mathrm{N}_{2}, \mathrm{H}_{2}, \mathrm{CO}$, $\mathrm{CO}_{2}$, and $\mathrm{CH}_{4}$ ) to find the area of each curve drawing by the G.C for each gas. A computer program compares between standard curves with drawn curves of unknown gases to limited type of gas.

Experiments Results in the laboratory of Basra Fertilizers Plant at different efficiencies $100 \%, 75 \%$ and $70 \%$ are summarized in Tables (2) and (3).

Table (2) input data of the industrial Secondary Reformer reactor in the laboratory of S.C.F.S.R. (Experimental Data) [6]

\begin{tabular}{|c|c|c|c|c|c|c|}
\hline \multirow{3}{*}{ Parameters } & \multicolumn{6}{|c|}{ Mole fractions (\%) } \\
\hline & \multicolumn{3}{|c|}{$\begin{array}{l}\text { Input Process Gases to } \\
\text { Secondary Reformer } \\
\text { Plant Efficiency }\end{array}$} & \multicolumn{3}{|c|}{$\begin{array}{l}\text { Input air to } \\
\text { Secondary Reformer } \\
\text { Plant Efficiency }\end{array}$} \\
\hline & $100 \%$ & $70 \%$ & $65 \%$ & $100 \%$ & $70 \%$ & $65 \%$ \\
\hline Temp. $\left({ }^{\circ} \mathrm{C}\right)$ & 795 & 737 & 739 & 550 & 528 & 522 \\
\hline Press. (Bar) & 32 & 32 & 30.5 & 32 & 32 & 30.5 \\
\hline $\mathrm{S} / \mathrm{G}$ & 0.852 & 0.870 & 0.860 & - & - & - \\
\hline Comp. & \multicolumn{6}{|c|}{ Mole Fractions components (Dry gases) } \\
\hline $\mathrm{CH}_{4}$ & 0.098 & 0.101 & 0.097 & & - & \\
\hline $\mathrm{H}_{2}$ & 0.678 & 0.712 & 0.693 & & - & \\
\hline $\mathrm{CO}$ & 0.093 & 0.062 & 0.070 & & - & \\
\hline $\mathrm{CO}_{2}$ & 0.124 & 0.115 & 0.132 & & 0.0003 & \\
\hline $\mathrm{N}_{2}$ & 0.003 & 0.007 & 0.006 & & 0.780 & \\
\hline $\mathrm{Ar}$ & 0.001 & - & - & & 0.009 & \\
\hline $\mathrm{O}_{2}$ & - & - & - & & 0.209 & \\
\hline
\end{tabular}

Table (3) output data of the industrial Secondary Reformer reactor in the lab of S.C.F.S.R. (Experimental Data) [6].

\begin{tabular}{lccc}
\hline Parameters & \multicolumn{3}{c}{$\begin{array}{c}\text { Mole fractions (\%) } \\
\text { Plant Efficiency }\end{array}$} \\
\hline Temperature $\left({ }^{\circ} \mathrm{C}\right)$ & $\mathbf{1 0 0 \%}$ & $\mathbf{7 0 \%}$ & $\mathbf{6 5 \%}$ \\
Pressure $(\mathrm{Bar})$ & 31.5700 & 909 & 867 \\
Components & Mole Fractions of components & (Dry gases) \\
$\mathrm{CH}_{4}$ & 0.0030 & 0.0029 & 0.0021 \\
$\mathrm{H}_{2}$ & 0.5552 & 0.5795 & 0.5711 \\
$\mathrm{CO}$ & 0.1264 & 0.1069 & 0.1058 \\
$\mathrm{CO}_{2}$ & 0.0907 & 0.0980 & 0.0948 \\
$\mathrm{~N}_{2}$ & 0.2211 & 0.2127 & 0.2262 \\
$\mathrm{Ar}$ & 0.0036 & - & - \\
$\mathrm{O}_{2}$ & - & - & - \\
$\mathrm{H}_{2} / \mathrm{N}_{2}$ & 2.5100 & 2.7240 & 2.5240 \\
$\left(\mathrm{H}_{2}+\mathrm{CO}\right) / \mathrm{N}_{2}$ & 3.0836 & 3.2270 & 2.9920 \\
\hline
\end{tabular}

\section{Mathematical Model}

The mathematical model of Secondary Reformer reactor examined to evaluate the reactions rate, the reaction effectiveness factors, the mass and heat transport limitations [1].

In Secondary Reformer reactor, five reactions take place i.e. the partial and complete combustion of methane and 
Hydrogen respectively, methane steam reforming to $\mathrm{CO}$ and H2 (and to CO2) and Water Gas Shift as follow[7]:

$\mathrm{CH}_{4}+3 / 2 \mathrm{O}_{2} \rightarrow \mathrm{CO}+2 \mathrm{H}_{2} \mathrm{O}$ (Partial Combustion of Methane)(1)

$\mathrm{H}_{2}+1 / 2 \mathrm{O}_{2} \rightarrow \mathrm{H}_{2} \mathrm{O}$ (Complete Combustion of Hydrogen)

$\mathrm{CH}_{4}+\mathrm{H}_{2} \mathrm{O} \leftrightarrow \mathrm{CO}+3 \mathrm{H}_{2}$ (Steam Methane Reforming)

$\mathrm{CH}_{4}+2 \mathrm{H}_{2} \mathrm{O} \leftrightarrow \mathrm{CO}_{2}+4 \mathrm{H}_{2}$ (Carbon Dioxide Reforming)

$$
\mathrm{CO}+\mathrm{H}_{2} \mathrm{O} \leftrightarrow \mathrm{CO}_{2}+\mathrm{H}_{2} \text { (Water Gas Shift) }
$$

$$
Q_{I N} \text { Air }+Q_{I N} \text { Processgases }=Q_{\text {OUT }} \text { Total }
$$

Mass and heat balances of i-component in axial direction are based on an adiabatic one dimensional heterogeneous catalytic reaction model. It can be estimated by the following equations [5]:

$$
\left(\partial F_{i} / \partial \ell\right)=\sum_{k=1}^{3} v_{i, k} \eta_{k} \cdot R_{k} \cdot \rho_{C}\left(1-\varepsilon_{B}\right) \cdot A
$$

The gas temperature throughout the reactor length can be written [8]:

$$
\left(\partial T_{g} / \partial \ell\right)=\sum_{k=1}^{3}\left(-\Delta H_{r, k}^{\circ}\right) \cdot \eta_{k} \cdot R_{k} \cdot \rho_{C}\left(1-\varepsilon_{B}\right) \cdot A / F_{g} \cdot C_{P . g} \cdot \rho_{g}(8)
$$

in heterogeneous reactions, temperature of catalyst surface is very important factor. It can be calculated as [5]:

$$
T_{s}=T_{g}+\left(\left(\left(\sum\left(-\Delta H_{r, k}^{\circ}\right) \cdot \eta_{k} \cdot R_{k}\right) \cdot \rho_{C}\left(1-\varepsilon_{B}\right) \cdot D_{S}\right) /\left(6 \cdot h \cdot\left(1-\varepsilon_{B}\right)\right)\right.
$$

\section{Result and Discussion}

\subsection{Reactants and Products}

In this section, the effect of air molar flowrates is investigated with mole fraction of Methane, Hydrogen and Nitrogen at Different Operation Plant Efficiencies of ammonia plant $100 \%, 70 \%$ and $65 \%$ in both combustion and catalyst sections.

Figures (1) to (3) show the effect of air molar flowrates on the mole fractions of methane, Hydrogen and Nitrogen $\left(\mathrm{CH}_{4}, \mathrm{H}_{2}\right.$ and $\left.\mathrm{N}_{2}\right)$ in the combustion and catalyst sections at Different Operation Plant Efficiencies 100\%, 70\% and 65\%.

Figure (1) depicts the profile of methane mole fraction as a function of inlet air molar flowrates for Different Operation Plant Efficiencies at 100\%, 70\% and 65\% in the outlet of combustion and catalyst sections.

The methane mole fraction in the Reformat Gases outlet from the combustion section decrease proportionally with an increase of air molar flowrates due to the methane reacts with oxygen content in the air. Also, the methane mole fraction decline along the catalyst section. Therefore the optimum of air molar flowrate is $1750.50 \mathrm{Kmol} / \mathrm{hr}$ at operation efficiency $100 \%$, while they are 1224.31 and $1136.855 \mathrm{Kmol} / \mathrm{hr}$ at operation efficiencies $70 \%$ and $65 \%$.

The theoretical and experimental values from Figure (2) and Table (3) respectively, show and confirm the agreement between the theoretical and experimental values of the Nitrogen mole fraction as a function of the inlet air molar flowrates for various plant efficiencies at 100\%, 70\% and $65 \%$ in the combustion and catalyst sections. The Nitrogen mole fraction in the Reformat Gases outlet from the Secondary Reformer increases proportionally with an increase of molar flowrates of air.

Also, The theoretical and experimental values from Figure (3) and Table (3) respectively, show and confirm same agreement between the simulation and industrial values of the profile of Hydrogen mole fraction as a function of inlet air molar flowrates at different various plant efficiencies in the Reformat Gases outlet from combustion and catalyst sections.

The Hydrogen mole fraction in the gas outlet from the combustion section decreases proportionally with an increase of molar flowrates of air due to the Hydrogen reacting with oxygen content in the air (the Hydrogen consumption) as shown in equation (2) at Different Operation Plant Efficiencies of ammonia plant 100\%, 70\% and $65 \%$.

\subsection{The Molar Ratio of Synthesis Gas to Nitrogen}

In this section, the influence of air molar flowrates on the molar ratio of synthesis gas $\left(\mathrm{H}_{2}+\mathrm{CO}\right)$ to Nitrogen is discussed at various ammonia plant conditions $100 \%, 70 \%$ and $65 \%$.

For optimum production of ammonia, a value of 3 for the molar ratio of synthesis gas to Nitrogen should be maintained. The molar ratio of synthesis gas to Nitrogen also shows a maximum with decreasing air molar flowrates at $100 \%, 70 \%$ and $65 \%$ because the Nitrogen content in the air decreases. Therefore, optimum air molar flow rate are $1750.50,1224.31$ and $1136.855 \mathrm{Kmol} / \mathrm{hr}$ at operation efficiencies $100 \%, 70 \%$ and $65 \%$ respectively.

\subsection{Temperature of Gases}

The effect of air molar flowrates on the outlet temperature of gases is described by equation (8).

Figure (5) shows the effect of inlet air molar flowrates on the temperature of gases at three plant efficiencies $100 \%$, $70 \%$ and $65 \%$ in the Reformat Gases outlet from combustion and catalyst sections.

Gas temperatures in the two sections increase with an increase of the air molar flowrates, Increasing temperature in the catalyst section is slightly lower than that of the combustion section, Therefore, conversions of endothermic reforming reactions increase with increasing of inlet temperature of the catalyst section. 


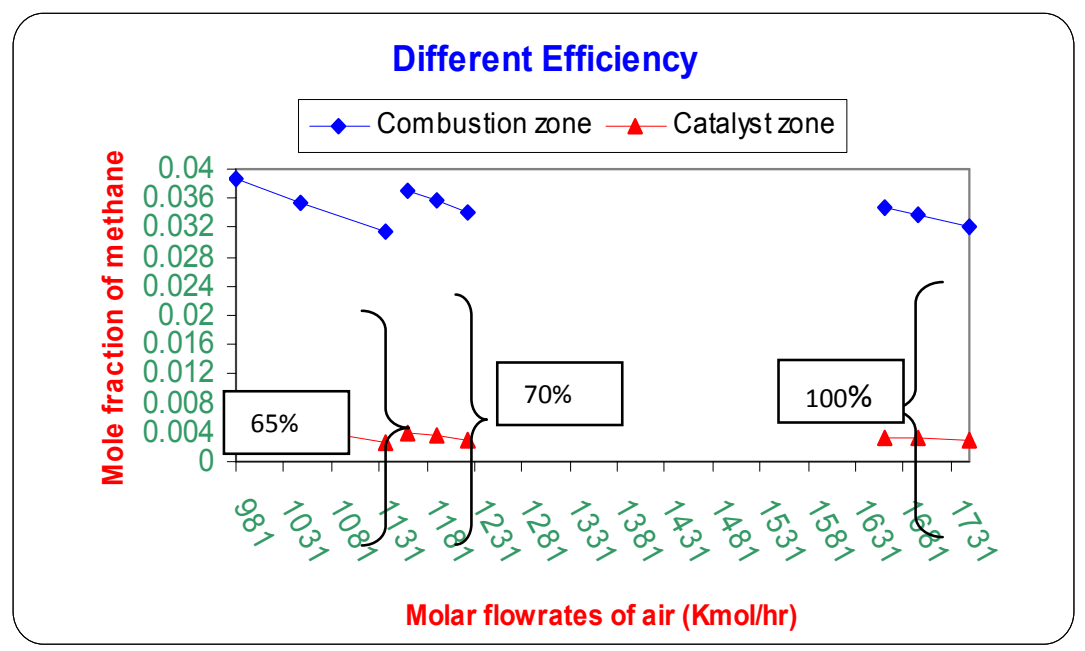

Figure (1) the effect of air molar flowrates on the Methane mole fraction in the Reformat Gases outlet from combustion and catalyst sections (Dry gases) at three Different Operation Plant Efficiencies $100 \%, 70 \%$ and $65 \%$ (Theoretical results).

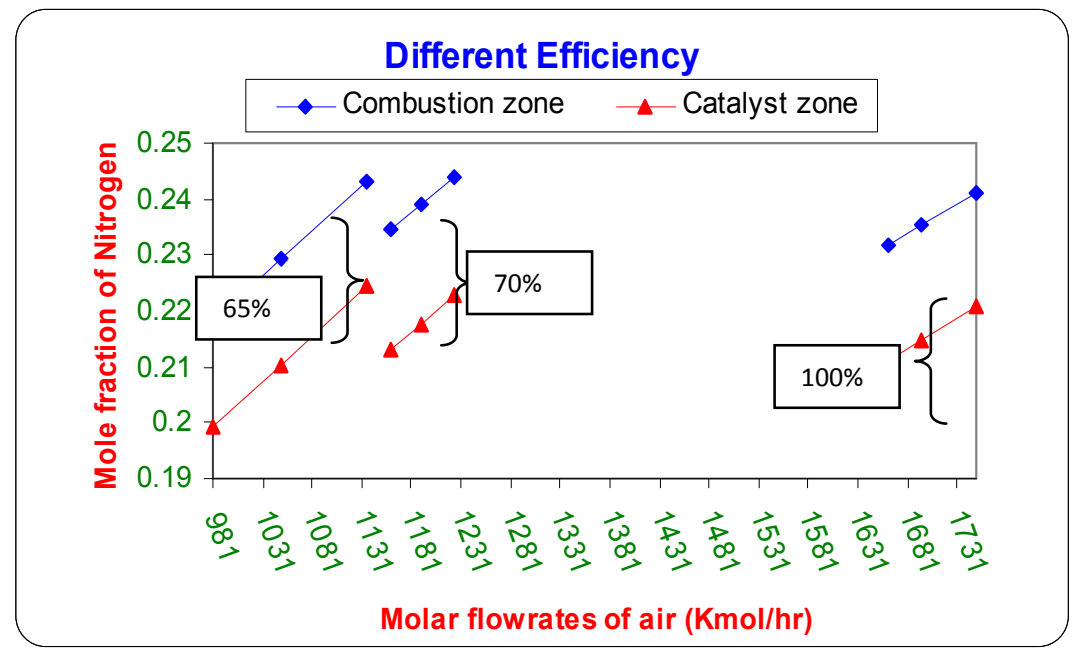

Figure (2) the effect of air molar flowrates on the Nitrogen mole fraction in the Reformat Gases outlet from combustion and catalyst sections (Dry Gas) at three Different Operation Plant Efficiencies 100\%, 70\% and 65\%( Theoretical results).

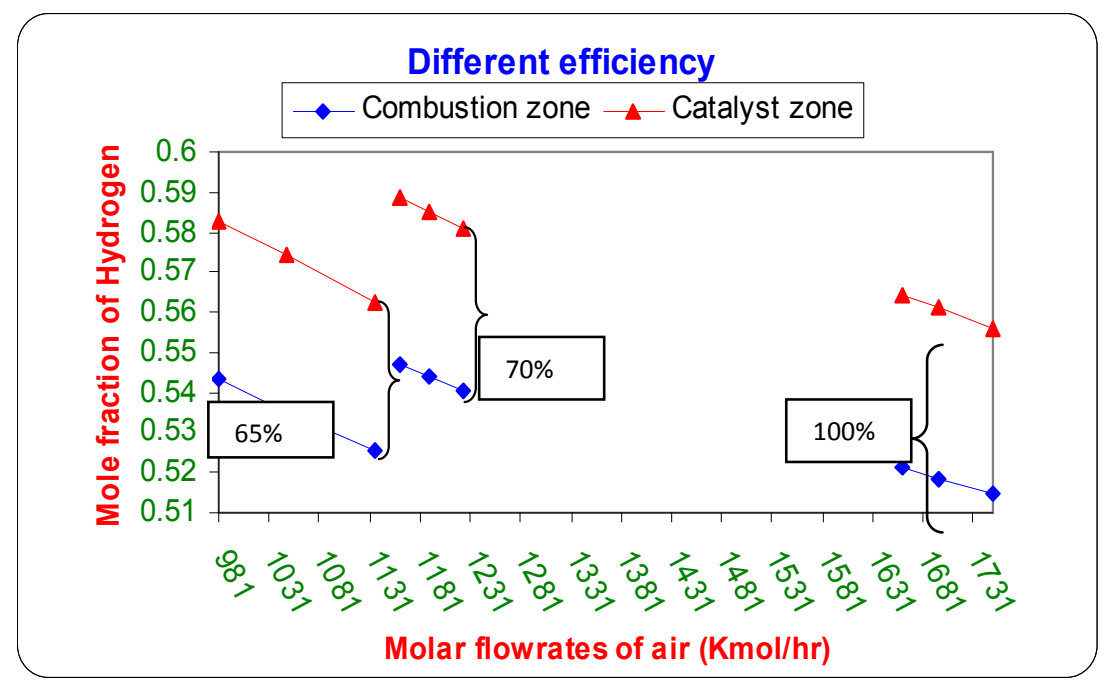

Figure (3) the effect of air molar flowrates on the Hydrogen mole fraction in the Reformat Gases outlet from combustion and catalyst sections (Dry Gas) at three Different Operation Plant Efficiencies 100\%, 70\% and $65 \%$ ( Theoretical results). 


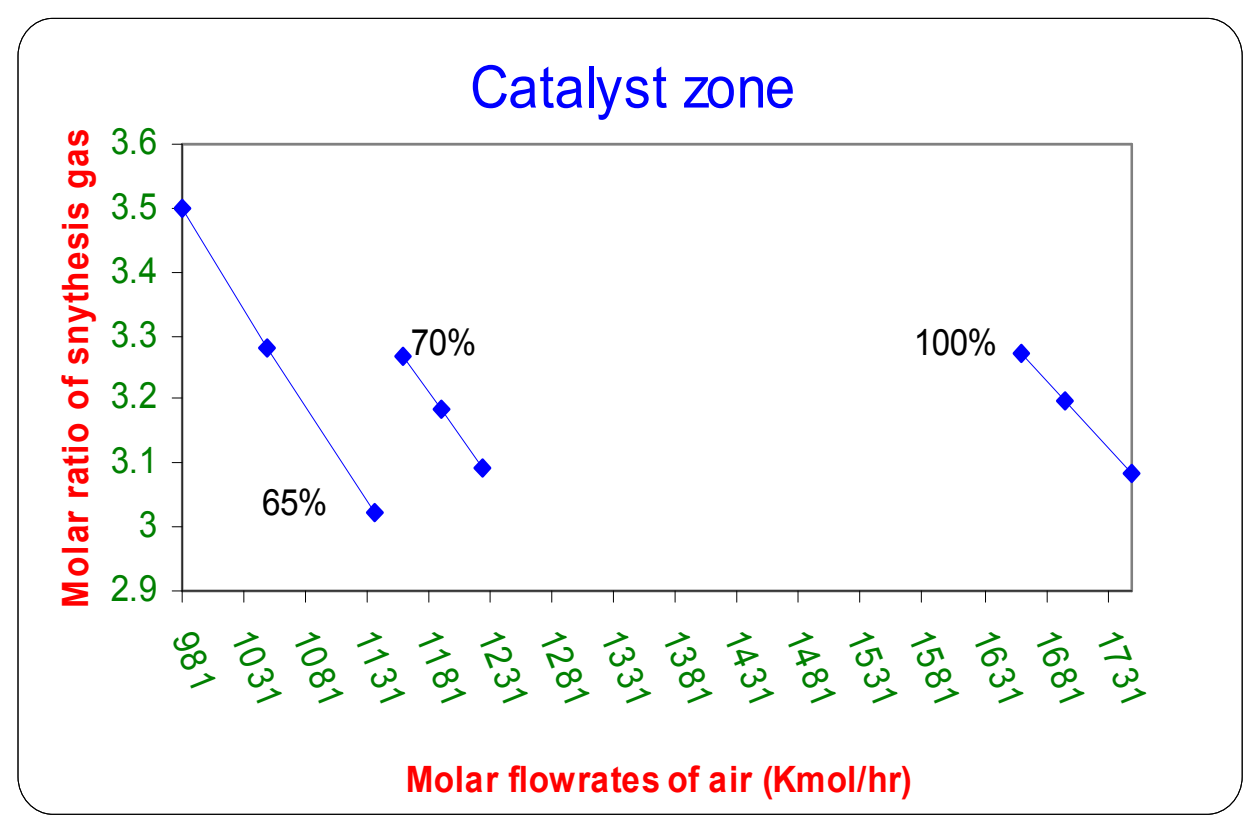

Figure (4) the effect of the air molar flowrates on molar ratio of synthesis gas to Nitrogen in the Reformat Gases outlet from Secondary Reformer at Different Operation Plant Efficiencies 100\%,70\%and 65\% (Theoretical results).

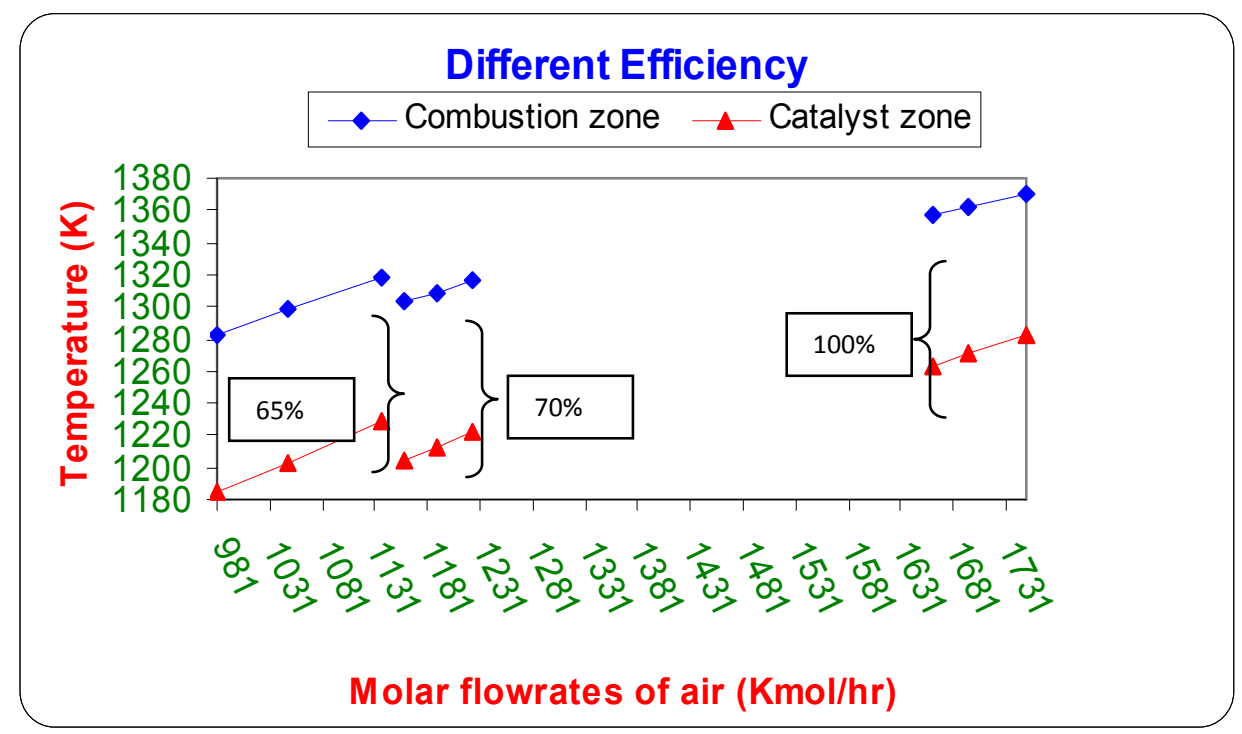

Figure (5) the effect of air molar flowrates on the temperature of gases outlet from Secondary Reformer at difference operation efficiencies $100 \%, 70 \%$ and $65 \%$ (Theoretical results).

\subsection{Reactor Cooling Water}

The effect of air molar flowrates on the total heat of combustion section in the Secondary Reformer is described by equation (6) in the combustion section. Table (4), shows the effect of inlet air molar flowrates on the total heat of gases in the combustion section relative to three Different Operation Plant Efficiencies at $100 \%, 70 \%$ and $65 \%$. In the combustion section relative to an operation efficiency at $100 \%$, the air molar flowrates vary between (1661.56 to $1750.5) \mathrm{Kmol} / \mathrm{hr}$, So the total heat of gases is fixed at ($\left.2.59^{*} 10^{5}\right) \mathrm{KJ} / \mathrm{s}$. While the total heat of gases for operation efficiencies at $70 \%, 65 \%$ in the combustion section have remind at $\left(-1.83 * 10^{5}\right) \mathrm{KJ} / \mathrm{s}$ and $\left(-1.74 * 10^{5}\right) \mathrm{KJ} / \mathrm{s}$ respectively.

The molar flowrate of cooling water around the Secondary Reformer is considered constant however; the flowrate of inlet air variable because, the heat of combustion section is depended on the heat of Process Gases from Primary Reformer.

Although, the heat of air increases when the molar flowrates of air increases but, that does not affect on the total heat of the combustion section as shown in Figure (6) due to the heat of Process Gases larger than the heat of air i.e. heat of Process Gases controls on the total heat in the combustion section. That means cooling water is remained with constant molar flowrate. 
Table (4) the effect of molar flowrates of air on the Total heat of gases in the combustion section at Different Operation Plant Efficiencies $100 \%$, 70\% and $65 \%$.

\begin{tabular}{llll}
\hline $\mathbf{1 0 0} \%$ & Heat of Process Gases (Inlet) & $\begin{array}{l}\text { Heat of Air } \\
\text { (Inlet) (Theory) }\end{array}$ & $\begin{array}{l}\text { Total Heat } \\
(\text { Outlet) (Theory) }\end{array}$ \\
\hline $\mathrm{F}_{\mathrm{air}}(\mathrm{Kmol} / \mathrm{hr})$ & $\mathrm{Q}(\mathrm{KJ} / \mathrm{s}) * 10^{5}$ & $\mathrm{Q}(\mathrm{KJ} / \mathrm{s}) * 10^{3}$ & $-\mathrm{Q}(\mathrm{KJ} / \mathrm{s}) * 10^{5}$ \\
1750.500 & -2.660 & 6.940 & -2.590 \\
1696.000 & -2.660 & 6.730 & -2.590 \\
1661.560 & -2.660 & 6.590 & -2.590 \\
$\mathbf{7 0} \%$ & & & $\mathrm{Q}(\mathrm{KJ} / \mathrm{s}) * 10^{5}$ \\
$\mathrm{~F}_{\mathrm{air}}(\mathrm{Kmol} / \mathrm{hr})$ & $\mathrm{Q}(\mathrm{KJ} / \mathrm{s}) * 10^{5}$ & $\mathrm{Q}(\mathrm{KJ} / \mathrm{s}) * 10^{3}$ & -1.830 \\
1224.310 & -1.880 & 4.620 & -1.830 \\
1190.340 & -1.880 & 4.490 & -1.830 \\
1160.050 & -1.880 & 4.380 & \\
$\mathbf{6 5 \%}$ & & & $\mathrm{Q}(\mathrm{KJ} / \mathrm{s}) * 10^{5}$ \\
$\mathrm{~F}_{\mathrm{air}}(\mathrm{Kmol} / \mathrm{hr})$ & $\mathrm{Q}(\mathrm{KJ} / \mathrm{s}) * 10^{5}$ & $\mathrm{Q}(\mathrm{KJ} / \mathrm{s}) * 10^{3}$ & -1.740 \\
1136.855 & -1.780 & 4.230 & -1.740 \\
1049.400 & -1.780 & 3.900 & -1.740 \\
981.580 & -1.780 & 3.650 & \\
\hline
\end{tabular}

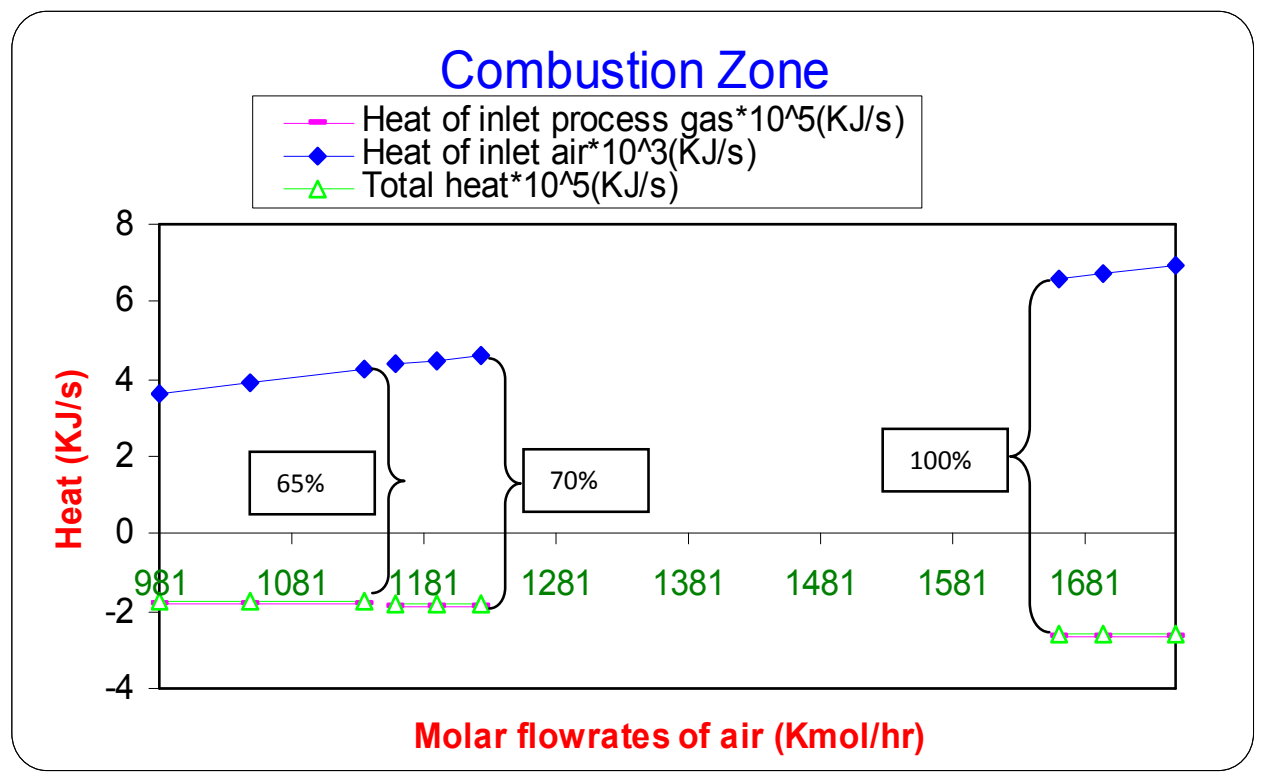

Figure (6) the effect of air molar flowrates on the total heat of gases in the combustion section at three Different Operation Plant Efficiencies $100 \%, 70 \%$ and $65 \%$.

\section{Conclusion}

In this study, the influence of molar flowrates of air on the optimum performance of the industrial Secondary Reformer reactor of the State Company of Fertilizers South Region is investigated, optimized and discussed. Several samples of feed and product gases from the industrial Secondary Reformer reactor are collected and analyzed in the laboratory of Basra Fertilizers Plant at Different Operation Plant Efficiencies of ammonia plant 100\%, 70\% and $65 \%$. Also, the operation conditions (Temperature and Pressure of feed) are read from manual, documents and daily $\log$ sheets of the industrial Secondary Reformer reactor. In the laboratory the analysis of feed gases (Process Gases) to the Secondary Reformer is used as data in the mathematical model then, the results of model comprised with the products gases (Reformat Gases) which are tested in laboratory to optimized molar flow rate of air at each operation efficiency.

The results show good agreement between theoretical and experimental values. This agreement approves the ability of using the predicting mathematical model and computer program for testing and finding the optimum operation conditions for the State Company Fertilizers Plant South Region.

In this paper, the optimum air Molar flow rate can be obtained according to the least methane mole fraction in the Reformat Gases outlet from the combustion and catalyst sections. Also, the molar ratio of synthesis gas to Nitrogen show 3 to 1 at $1750.50,1224.31$ and $1136.855 \mathrm{Kmol} / \mathrm{hr}$ of air molar flowrate at different operation plant efficiencies $100 \%, 70 \%$, and $65 \%$. 
The molar flowrate of cooling water around the Secondary Reformer is considered constant however; the flowrate of inlet air variables in the combustion section of Secondary Reformer.

\section{Acknowledgement}

The author would like to acknowledge the State Company Fertilizers South Region in Basra/Iraq to active contribution to successful this work.

\section{Nomenclature}

$A=$ Cross section area $\left(\mathrm{m}^{2}\right)$.

$\mathrm{C}_{\mathrm{P}}=$ Specific heat capacity $(\mathrm{KJ} / \mathrm{kmol} . \mathrm{K})$.

$\mathrm{D}_{\mathrm{S}}=$ Equivalent pellet diameter $(\mathrm{m})$. This is defined as the diameter of a sphere with the same external surface area per unit volume of the catalyst pellet $D_{s}=6 .\left(1-\varepsilon_{B}\right) / S_{B}$.

$\mathrm{F}=$ Molar flowrate $(\mathrm{Kmol} / \mathrm{hr})$.

$\mathrm{h}=$ Heat transfer coefficient $\left(\mathrm{KJ} / \mathrm{m}^{2} . \mathrm{K} . \mathrm{hr}\right)$ $h=\left(N u \cdot K / D_{S}\right)$.

$\Delta \mathrm{H}_{\mathrm{r}, \mathrm{k}}^{\mathrm{o}}=$ Standard heat of reaction $\mathrm{k}(\mathrm{KJ} / \mathrm{mol})$.

$\ell$ axial coordinates $(\mathrm{m})$.

Q Heat amount $(\mathrm{KJ} / \mathrm{Kmol})$.

$\mathrm{R}_{\mathrm{k}}$ Rate of reaction for reaction $\mathrm{k}\left(\mathrm{Kmol} / \mathrm{Kg}_{\text {cat }} \cdot \mathrm{hr}\right)$.

$\mathrm{T}$ Temperature $(\mathrm{K})$.

\section{Greek letters}

$\varepsilon_{\mathrm{B}}$ Porocity of packed bed $\left(\mathrm{m}^{3}{ }_{\text {void }} / \mathrm{m}_{\mathrm{r}}{ }^{3}\right)$

$\eta_{\mathrm{k}}$ Reaction effectiveness factor for reaction $\mathrm{k}$ (dimensionless unit).

$v_{i}$ Stoichiometric coefficient of i- component in the chemical reactions equations (dimensionless unit).

$\rho_{\mathrm{c}}$ Density of catalyst $\left(\mathrm{kgc} / \mathrm{m}_{\mathrm{r}}{ }^{3}\right)$

\section{Abbreviations}

C.D.R Carbon Dioxide Reforming.

g Gas.
IN Inlet stream.

OUT outlet stream.

S.C.F.S.R. State Company of Fertilizers South Region.

S.M.R Steam Methane Reforming

S Catalyst Surface.

W.G.S Water Gas Shift

\section{References}

[1] A. A. AL-Dhfeery and A. A. Jassem, "Modeling and Simulation of an Industrial Secondary Reformer Reactor in the Fertilizer Plants," International Journal of Industrial Chemistry (IJIC), Vol. 3, (2012). doi:10.1186/2228-5547-314

[2] A.A.AL-Dhfeery and A.A.Jassem, "Evaluation Performance of Different Types Catalysts of an Industrial Secondary Reformer Reactor in the Ammonia Plants," Modern Research in Catalysis, Vol. 1, No. 3, P: 43-51, (2012). doi: 10.4236/mrc.2012.13006

[3] M.I.Shukri, A.R.Songip, A.Ahmad and N.S.Nasri, "Simulation Study of Methane Autothermal Reforming for Hydrogen Production" Advanced in fuel cell research and development (Malysia), P: 149-158, (2004).

[4] D.L.Hoang and S.H.Chan, "Modeling of a Catalytic Autothermal Methane Reformer for Fuel Cell Applications", Applied Catalysis J., Vol.268, P: 207- 216, (2004).

[5] Y.H.Yu, "Simulation of Secondary Reformer in Industrial Ammonia Plant", Chem. Eng. Tech. J., Vol.25, P: 307-314, (2002).

[6] Documents of State Company of Fertilizer South Region (S.C.F.S.R. ).

[7] A. A. AL-Dhfeery and A. A. Jassem, " Study of Chemical Reactions Effect on the Design and the Performance of an Industrial Secondary Reformer Reactor in the Fertilizers Plants", International Journal of Applied Sciences and Engineering Research (IJASER), Vol. 2, No. 1, P: 60-69, (2013).

[8] J.M.Smith "Chemical Engineering Kinetics", Chemical Engineering Series, (1970). 